SOKAL, R. R. \& ROHLF, F. J. 1981. Biometry (Second Edition). W. H. Freeman Cempany, San Francisco, California, USA.

STEVENS, G. C. 1987. Lianas as structural parasites: the Bursera simarouba example. Ecology 68:77-81.

SWAINE, M. D. \& WHITMORE, T. C. 1988. On the definition of ecological species groups in tropical rain forests. Vegetatio 75:81-86.

TODZIA, C. 1986. Growth habits, host tree species, and density of hemiepiphytes on Barro Colorado Island, Panama. Biotropica 18:22-27.

WHITMORE, T. C. 1975. Tropical rain forests of the Far East. Clarendon Press, Oxford.

Accepted 6 September 1989

\title{
ANNOUNCEMENT
}

\section{Conservation and management of tropical inland waters: problems solutions and prospects}

A meeting to be held in Hong Kong during the first week of September in 1991

The rate of degradation of tropical inland-water habitats cannot fail to alarm limnologists everywhere. Our need to protect these habitats is, however, hampered by our lack of know. ledge of tropical systems. The proposed meeting aims to bring together limnologists from both tropical and temperate regions, and help serve the purpose of protecting tropical inland waters by summarizing current knowledge, identifying areas where there are significant gaps in understanding, and indicating how these gaps may be filled using rigorous methods employed in such a manner as to answer specific questions. In particular, we can focus on approaches which will shed light on both the similarities and dissimilarities in patterns and processes operating in tropical and temperate regions.

This meeting will consist of several sessons covering the following topics:

(1) Running waters: ecology and management;

(2) Standing waters and man-made lakes: ecology and management;

(3) Freshwater pollution and toxicology;

(4) Freshwater fisheries and aquaculture;

(5) Ways ahead: practical, logistic and funding considerations in the protection of tropical inland waters.

It is intended that the edited and refereed proceedings of this meeting be published in book form.

Interested persons should contact one of the undersigned:

Dr David Dudgeon

Department of Zoology, University of Hong Kong, Pokfulam Road, Hong Kong

Dr Paul K. S. Lam

Department of Applied Science, City Polytechnic of Hong Kong, Tat Chee Avenue, Kowloon, Hong Kong 